\title{
The Role of Banks in Small and Medium Enterprises Financing: A Case Study from Kosovo
}

\author{
Qazim Tmava ${ }^{1}$, Florin Peci ${ }^{2} \&$ Gazmend Luboteni ${ }^{1}$ \\ ${ }^{1}$ Faculty of Economics, University of Prishtina, The Republic of Kosovo \\ ${ }^{2}$ Faculty of Business Administration, University of Peja, The Republic of Kosovo \\ Correspondence: Florin Peci, Faculty of Business Administration, University of Peja, Peja, The Republic of \\ Kosovo. Tel: 377-44-787-897. E-mail: florin.peci@unhz.eu
}

Received: September 9, 2013

Accepted: October 18, 2013

Online Published: November 26, 2013

doi:10.5539/ijef.v5n12p94

URL: http://dx.doi.org/10.5539/ijef.v5n12p94

\begin{abstract}
In this study we investigate the impact of firm and entrepreneurship characteristics in small and medium enterprises (SME-s) investment finance through debt (bank loan). Data are gathered from interviews based on a self-organized questionnaire with 150 SME-s in Kosovo. Based on the econometric model of linear regression, key factors are identified which influence the investment growth financed by debt. The results indicate that there is mutual correlation among the firm's age, size, business plan, sector, number of owners, sources of financing and the investment growth financed from banks in Kosovo. Therefore, findings in this work suggest that the access to external sources of financing through bank loan is an important factor that influences the investment growth. The paper provides some important conclusions and implications for policymakers and entrepreneurs.
\end{abstract}

Keywords: SME, entrepreneurship, financing through debt, investment, Kosovo

\section{Introduction}

It is explicitly accepted that SME-s present a pivotal element in the economic activity in both, developed and developing countries (Acs \& Audretsch, 1990; Johnson \& Loweman, 1995). Numerous authors from academic and professional world designate SME-s as generators of both, economic growth and overall social development (Audretsch \& Klepper, 2000; World Bank Group, 2005; McMillan \& Woodruff, 2002).

The discussion of the relevant literature related to the access of SME-s to finance, as well as to investment finance is of particular importance (Krasniqi, 2007). According to Beck et al. (2007), the SME-s access to, and cost of, finances is quite often characterized as a major difficulty, up to the extent of 35 percent. It should also be stressed that the small firms come with more difficulty to loans, since they encounter higher transaction costs and higher premium risks, for they are more fragile and they offer lower collaterals (Beck et al., 2006). Audretsch and Elston (2006) also stress that small firms confronted higher financial difficulties than large ones. Similar conclusions can be found among other authors who have worked in this direction (Beck et al., 2006; Oliveira \& Fortunato, 2006).

Brinckmann et al. (2011) finds that small firms have higher limitations to access external sources of financing than bigger firms, and, thus, they become more dependent on internal funds for financing their investment needs. A major obstacle in financial markets to the access on finances by SME-s is also the asymmetry of information. Thus, based on Zhao et al. (2006), one from the major difficulties for accessing finance is the asymmetry of information among lenders and debtors; for instance, borrowers have private information on the firm that lenders do not possess. Because of their small size, short history and inconsistent accounting data, the issue of asymmetric information for SME-s becomes more serious (Deakins et al., 2008; EBRD, 1999; Pissardies et al., 2003; Klapper et al., 2002).

Difficulties of this kind are expressed also among SME-s of Kosovo, as one from the last countries in transition. In spite of the fact that the SME sector in Kosovo is relatively new, it constitutes $98 \%$ of all the firms, thus representing a huge potential for generation of new jobs and for economic development of the country. Based on data of the World Bank (2010), the major obstacle to the development of SME-s in Kosovo is access to bank loans. Only $10 \%$ of investments made by SME-s are financed through bank loans, and above $85 \%$ of investments are financed from private sources (World Bank, 2010). 
Objective of this work is to empirically investigate the role and importance of the firms and entrepreneurship characteristics that influence the investment growth through debt finance (loans) in Kosovo. Therefore, the research question in this study is: How does the investment growth impact the performance of SME-s, by discussing the firm and entrepreneurship characteristics of the investment growth of SME-s in Kosovo?

The organization of the work is as following: Part one discusses the context of the research, part two the theoretical aspect and the summary of literature. In part three we provide the research methodology and model. Part four contains the results and empirical findings. And, part five deals with the conclusions.

\section{Theory and Literature Review}

Until now, there is no single and unique theoretical model that explains the financing of SME-s, which influences the performance of investments, their growth and development. The theoretical principles underlying capital structure can generally be describes in terms of the static trade off theory by Modigliani and Miller (1958), the pecking order theory (Myers \& Majluf, 1984), managerial theory of investments (Marris, 1963; Baumol, 1967), agency theory by Jensen and Meckling (1976) and extended by Stiglitz and Weiss (1981).

According to neoclassical theory of investments (M-M), which affirms the attitude on the irrelevance of the capital structure for the value of the firm, internal and external sources of financing are perfect substitutes. In the world of the perfect functioning of the market, the choice between financing through capital or debt is irrelevant. Therefore, the cost of capital and the market value of the firm are independent from the value of the firm (Modigliani \& Miller, 1958). The theory of M-M is based on the following premises: there are no taxes, there are no transaction costs, there are no bankruptcy costs, the equal cost of debt for companies and for investors, symmetrical information in the market, there is no influence of debt in the profit of the company before interest and taxation.

Modigliani and Miller (1958) modify their theory by introducing the tax on profit. In this case, the value of the firm is positively related to debt. After introducing the tax on profit in their analysis, they ascertain that the financial leverage increases the value of the firm, since the interest decreases the tax base (it is deduced from the business profit), and, therefore, we have savings which have the value of the interest. From this ascertainment, the value of the firm grows bigger, as the financial leverage increases, which means that the highest value of the firm is achieved if the burden of debt becomes $100 \%$. In this way the firm attains absolute advantage, given that it is defended from taxes.

Scott (1972) emphasizes that $100 \%$ tax shield does not exist in reality, because of distress costs. Debt leads to legal obligation to pay interest and principal. If a firm cannot meet its debt obligation, it is forced in to bankruptcy an incurs associated costs (Fatoki \& Asah, 2011). This theory, in fact, does not take into the consideration all the other factors, such as: the costs of the bankruptcy of the firm, the costs of the agency, the impact of debt in profit, the asymmetry of information, and, therefore, this theory is challenged by other theories (Harris \& Raviv, 1991).

Thus, the static trade off theory, which is based on the M-M theory and is its complementary, except savings from the tax on profit, incorporates into the discussion also the cost of bankruptcy, such as: judicial taxes, attorney costs, administrative costs, and, also, the agency costs (the firms managers damage the interests of the creditors by working in the interest of shareholders), and this can reduce the value of the firm (Jensen and Meckling, 1976). This theory is, in fact, the dominant theory regarding the determination of the financial structure of the firm, and it is founded on the premise that it is the firm that chooses how much it will be financed from debt, and how much from the capital, by balancing the cost of profits. According to this theory, the optimal level of the structure of capital is the one which equates the profit and costs from debt.

According to pecking order theory, the firm initially prefers internal sources of financing to external ones, and, regarding external sources, they prefer debt to capital (Donaldson, 1961). Thus, initially we have the use of accumulated profit, amortization, debt, and, finally, the equity capital. According to this theory, the firms finance their investment requirements based on a hierarchic order. This can direct also to existence of the asymmetry of information between managers (insiders) and investors (outsiders). As a result of this, managers have more information then investors (Myers \& Majluf, 1984).

Based on the agency theory, Stiglitz and Weiss (1981) present the problem that, as a consequence of asymmetrical information, occur between managers and shareholders, on one hand, and the problem among shareholders, managers and creditors, on the other. They argue that only SME-s knows the real financial structure of their own, the real strength of their investment projects and the tendencies for settling up the debt, and, therefore, the firm possesses superior private information (Mazanai \& Fatoki, 2012). 


\section{Hypothesis}

\subsection{Business Plan}

According to Guffey, the business plan is a necessary requirement at the beginning of business, and it is used as an important element to acquire financial support during application to banking institutions (Guffey, 2008). An increase in the level of skills of those who are looking for credits in the compilation of business plans, will increase their opportunities to have properly prepared documentation, and to have a clear idea on the course of their business. According to Maziku (2012), the asymmetric information between the debt-seeking SME-s and the bank, is reflected in the incapability of the majority of SME-s to provide consistent financial data and real business plans, which increases the operational cost during the decision making for permitting the loans by the a bank (Maziku, 2012). Thus, the business plan does not have an impact only in reduction of operational costs, but it is also a key instrument in the decision making regarding the use of banking loans by the firms (Zhang, 2008; Madura, 2007). This is valid particularly for start-up businesses.

Therefore, the following hypothesis is generated:

H1: SME-s which have business plans are more likely to use bank loans than SME-s without written business plans.

\subsection{The Growth of the Firm}

The growth of SME-s depends on the level of investments. The growth of SME-s can be measured in different ways, including the growth of sales, profits, or number of employees (McPerson, 1996). We measure this variable through the growth of the number of employees.

The ability of SME-s to grow depends on a large measure from their potential to invest in the restructuring and innovations. All these investments require capital, that is, they require access to finance (Mazanai \& Fatoki, 2012). According to Ganbold (2008), in a research of the World Bank, one among the key difficulties in the growth of the firm is access to financial services, which reflects in economic growth, employment generation, and reduction of poverty in the developing countries (Ganbold, 2008). Based on the theory of firm growth (Jovanovic, 1982), new enterprises grow faster, which means that these have to invest more.

Therefore, the following hypothesis is generated:

H2: SME-s that grow faster invest more than those with low level of growth.

\subsection{Gender}

In the professional literature there are contradictory opinions regarding the impact that gender of the owner of the firm has into the access to finance. While a group of thinkers assert that gender of the owner has an impact into the capital structure of the firm, the other group denies this, ascertaining that gender doesn't have any impact into the determination of the capital structure.

On one hand, Abor (2008) argues that businesses owned by female owners use the debt (loans) less for different reasons, including discrimination and aversion to risk. Watson et al. (2009) emphasize that a key factor in determining the capital structure in businesses owned by female owners is their propensity towards not accepting risk from the desire to keep things under control. Female clients are more hesitant to seek loans, since they feel discriminated and discouraged (Kon \& Storey, 2003).

On the other hand, Coleman (2000) find that there ar no important differences in the use of debt (banking loan) between female and male owners, and that gender is not an important predictor of the financial leverage of the firm. Whereas, Irving and Scott (2008), analyzing 400 SME-s, and based on the questionare prepared by Barclays Bank, in the most surprising way ascertain that female have easier access to finance then male. Therefore, based on the findings reported above, the following hypothesis is generated:

H3: The male owners of firms are more likely to use bank loans then the female owners of firms.

\subsection{Sources of Financing}

The larger participation of investment finance from internal sources of SME-s increases the probability for acquiring of bank loans, since the internal sources carry the opportunity cost of financing of the project. Thus, SME-s provide higher level of trust to banks, since, in the case of failure, the unexpected burden falls on SME-s themselves. In their research conducted in 16 countries of OECD, Japelli and Pagano (1994) ascertain that banks don't finance $100 \%$ of the property value in any of these countries, but they do that with a certain coeficient loan/property. This is not equal for all the countries, and it differs from country to country, starting from the minimum financing of $50 \%$ in Turkey and Greece, up to $95 \%$ in Denmark. 
Thus, authors Lee and Ratti (2008) and Ahn et al. (2006) reports negative relationship between debt and investments. This relationship is stronger among smaller firms. As the debt (loans) grows, the cash flow is increasingly used for settling up the loan and its interest. Consequently, firms fulfill their obligations to creditors with more difficulties, and, on the other hand, the possibility for new investments is reduced.

Therefore the following hypothesis is generated:

H4: The higher the internal sources of SME-s, the higher probability to acquire bank loans for investment finance.

\subsection{Education}

Education is one of the important factors that influence the growth of the firm. Therefore, the high level of human capital (education and experience) has a positive impact in the growth of the firm. The owners of the firm who are of young age and low level of education are more active in using the external sources of financing, in spite of the fact that higher education reduces the fear for refusing the loans. In the meantime the owners of more mature age and with higher education, the so called "wiser" ones, can be found as less interested for external sources of financing (Vos et al., 2007). Therefore, the majorities of owners of SME-s prefer to keep the control and do not apply for external capital (Curran, 1986; Jarvis, 2000).

Thus, the internal capital is the major source of financing the SME-s (Ou \& Haynes, 2003). Rand (2007) finds also negative influence between education of owners-managers and access to credit, arguing that owners-managers with higher education can understand easier that their requirements for credits can be refused. Therefore, these owners-managers are for this reason discouraged and hesitate to apply for loans. In their study on new firms, Hartarska and Gonzales Vega (2006) find that education does not have an important role in the decision-making of the banks for lending.

Therefore, the following hypothesis is generated:

H5: Owners/managers with high level of education use less bank loans for financing the investment requirements.

\section{Methodology}

\subsection{Sources of Data}

The organization of data gathering from the questionnaire was developed in the period March-July, 2012, and data processing based on the answers was conducted in November and December 2012. On this occasion, a database was developed, which includes characteristics of SME-s in general, and characteristics related to investments and their financing in particular. Data processing was conducted with the STATA software.

The questionnaire is specially designed for this scientific research with 150 SME-s in Kosovo, and it includes years 2010 and 2011. The sample selection is made randomly, from database at the Agency for Businesses Registration in the Ministry of Industry and Trade of Kosovo, and it is stratified in three basic sectors, in order to reflect eventual changes among the production, trade and service firms. Interviews were conducted directly (face to face) with owners/managers, or financial managers of the firms.

\subsection{Questionnaire}

The questionnaire consisted of 4 major sections. The first section included data on the owner/manager of the firm, and general data about the firm (location, the year of establishment, type of activity, and qualification of owners/managers). Second section included the orientation regarding the development in the future as well as investments, and here are presented data regarding volume of investments, sources of investment, the use of bank loans in realization of investments, conditions of financing, activities that are conducted during the realization of investments, and investment plans for the future. The third section covers information regarding business activities of the firms inside and outside of the country, that is, whether a certain firm imports or exports merchandise. The fourth section includes data regarding the business plans of the firms: possession of the business plan, its impact on the decisions of the banks. Information gathered from the questionnaire was important for determining the variables in the econometric model of linear regression.

\section{Research Model}

The determination of the key variables enables us to definie the structure of the model with which we test the volume of investments and their growth in the Kosovan SME-s.

The structure of the econometric model is presented as following: 


$$
\begin{gathered}
Y=\alpha_{0}+\beta_{1} x_{1}+\beta_{2} x_{2}+\beta_{3} x_{3}+\beta_{4} x_{4}+\beta_{5} x_{5}+\beta_{6} x_{6}+\beta_{7} x_{7}+\beta_{8} x_{8}+\beta_{9} x_{9}+\mu \\
Y=\alpha_{0}+\beta_{1} \text { entre_edu }+\beta_{2} \text { inter_exter }+\beta_{3} \text { business_plan }+\beta_{4} \text { production }+\beta_{5} \text { trade }+\beta_{6} f \text { irm_age } \\
+\beta_{7}+\text { no_own }+\beta_{8} \text { size_emp }+\beta_{9} \text { gender }+\mu
\end{gathered}
$$

Dependent variable:

\section{$\boldsymbol{Y}=$ invest_growth}

Thus, dependent variable is invest_growth, and it presents the growth of investment in 2011.

Independent variables are coded as following:

entre_edu-coded as 1 for entrepreneurs who have finished university education, and coded as zero for entrepreneurs who don't have university education.

inter_exter-is measured as a ratio between investments made from internal sources with those financed from external sources.

business_plan-is coded as 1 for the firms that have business plan, and 0 otherwise.

production-is coded as 1 , for the firms in the sector of production, and 0 otherwise.

trade-is coded as 1 for the firms in the sector of trade, and 0 otherwise.

firm_age-expresses the number of years that the firm is in business activity.

no_own-indicates the number of owners.

size_emp-indicates the size of the firm expressed through the number of employees.

gender-indicates the gender of the owner/manager of the firm.

\section{Survey Results}

Based on the results, we conclude that the regression linear model mentioned above is specified good, given that Adj R-squared 0.36, which shows that the variation in independent variables explains the variation in dependent variable for more than $36 \%$. In addition, the statistical F-test, shows that all the independent variables, jointly, which are statistically significant, are different from zero.

Also, the correlation analysis shows that the problem of correlation in independent variables is not present in our data, given that there no higher coefficients in our estimation. Also, the dependent variable has a normal

\begin{tabular}{|c|c|c|c|c|c|c|c|c|c|}
\hline & Gender & production & trade & firm_age & no_own & entre_edu & inter_exter & size_emp & business_plan \\
\hline Gender & 1.0000 & & & & & & & & \\
\hline production & 0.1427 & 1.0000 & & & & & & & \\
\hline trade & -0.1585 & -0.1005 & 1.0000 & & & & & & \\
\hline firm_age & 0.2418 & 0.1336 & -0.1500 & 1.0000 & & & & & \\
\hline no_own & 0.1718 & 0.0753 & -0.0300 & 0.1491 & 1.0000 & & & & \\
\hline entre_edu & -0.0738 & -0.3259 & 0.3760 & -0.1318 & -0.1825 & 1.0000 & & & \\
\hline inter_exter & -0.1027 & -0.1047 & 0.0870 & -0.0308 & -0.2472 & 0.0695 & 1.0000 & & \\
\hline size_emp & 0.0551 & 0.1967 & -0.1400 & 0.084 & 0.4487 & -0.0914 & -0.2993 & 1.0000 & \\
\hline business_plan & -0.1677 & 0.1452 & -0.1200 & -0.3119 & -0.0565 & 0.2140 & -0.2636 & 0.1982 & 1.0000 \\
\hline
\end{tabular}
distribution and does not represent a statistical problem that requires treatment.

Table 1. Correlation between coefficients at 5\% level of significance

Source: Own calculation.

Based on the table 2, in which the results of the linear regression are presented, from nine independent variables, six are statistically significant with impact on the dependent variable, or on the investment growth. 
Table 2. Determinants of firm investments growth financing through external sources

\begin{tabular}{ccccccc}
\hline & invest_growth & Coef. & Std. Err. & $\mathrm{t}$ & $\mathrm{P}>|\mathrm{t}|$ & [95\% Conf. Interval] \\
\hline gender & -79.78481 & 64.51314 & -1.24 & 0.218 & -186.6064 & 27.03674 \\
trade & -925.6895 & 185.564 & -4.99 & 0 & -1232.948 & -618.4307 \\
production & -538.7114 & 189.8072 & -2.84 & 0.005 & -852.996 & -224.4267 \\
firm_age & -6.685608 & 4.383491 & -1.53 & 0.129 & -13.94384 & 572.6224 \\
entre_edu & -1.436477 & 48.20413 & -0.03 & 0.976 & -81.25338 & 78.38043 \\
inter_exter & 0.3603716 & 0.3966264 & 0.52 & 0.606 & -0.7931098 & 1.513853 \\
business_plan & 84.96332 & 39.14907 & 2.17 & 0.032 & 7.56351 & 162.3631 \\
size_emp & -25.66381 & 5.367756 & -4.78 & 0 & -34.5518 & -16.77583 \\
no_own & 146.4654 & 35.83314 & 4.09 & 0 & 87.13255 & 205.7938 \\
_cons & 984.5017 & 214.7547 & 4.58 & 0 & 628.9086 & 1340.095 \\
\hline
\end{tabular}

Source: Own calculation. $\mathrm{N}=150$, Adj.R2 $=0.36 \%$.

According to results, the variable business_plan, is statistically significant and with positive sign. This means that the firms that have business plans, on average have investment growths that are bigger than those of the firms that do not have business plans. Similar ascertainments can be found among other authors who emphasize that the business plan serves as a mean for increasing financing from external sources (Zhang, 2008).

The variable trade is statistically significant and with negative impact in the investment growth when compared with the firms that belong to the service sector. This has the meaning that services on average invest more than other sectors. In addition the variable production is also statistically significant and with negative impact on the increase of investments when compared with the firms that belong to the sector of services. This has the meaning that when compared with the services, the sector of production invests less than other sectors. Similar ascertainments for the case of Kosovo can be found in the work of the author Krasniqi (2010).

The next variable no_own, which indicates the number of owners, is statistically significant and with positive impact, which means that the greater the number of owners, the greater will be the investments. We have also size_emp as a variable that shows the size of the firm expressed by the number of employees, and is statistically significant and with inverse impact on the growth of investments. This means that smaller firms have larger investment growths. This finding clearly reflects that as the number of employee's grows, the firms grow slowlier. This is in full accordance with findings of other authors (Audretsch \& Klepper, 2000; Caves, 1998). These results are the same with other studies that oppose the Gibrat Law (Krasniqi, 2006; Harris \& Trainor, 2005).

The firm_age as an independent variable is statistically significant and with negative sign, which means that new firms grow faster than older firms. This ascertainment is in accordance with findings of many authors who ascertain that younger firms grow faster than the older ones, and, therefore, have higher investment growth (Woldie et al., 2008; Storey, 1994; Barkham et al., 1996).

The gender of the owner of the firm in the presented model, as a variable is not statistically significant, which means that the owners of the businesses of both genders have the same probability to obtain bank loans for SME-s investments. These results are in accordance with the studies conducted by Kalleberg and Leicht (1991), who, in a study conducted with 300 firms in three sectors, ascertain that female owners were as successful as male owners. We find similar ascertainment in the study of 298 businesses in United Kingdom, which emphasizes that gender, is not a determinant for financing the business (Johnson \& Storey, 1993). Coleman (2000) emphasizes that there are no important differences in the use of debt (bank loans) between males and females, and that gender is not an important predictor for financial leverage of the firm.

Finally, education represents a variable which is not statistically significant and has negative sign, which means that the level of education of the managers/owners doesn't impact external sources of financing (bank loans) for SME-s investments. This is explained by the fact that Kosovan SME-s suffer from permanent lack of capital, and on average the time frame of establishment is short and the means that are accumulated from the profits are insufficient for financing the investments. Therefore, the only alternative that remains to them is financing from banking credits, taking into the consideration that the capital market does not function in Kosovo, which causes 
that the possibility to use other forms of external financing is very difficult. Similar results can be found at Krasniqi (2010).

\section{Conclusions}

In this study we have investigated empirically the key factors of the firms and entrepreneurship which influence the increase of investment growth through bank loans. The data gathered by the self organized questionnaire with 150 SME-s in the entire territory of Kosovo for the years 2010 and 2011 are used to test the impact of certain factors in the increase of investments through the use of financial means from debt (bank loans). Based on the statistical analysis and the method of linear regression, key factors are identified as indicators that influence the growth of investments of SME-s in Kosovo.

The findings of this work stress that the business plan is a factor with statistical importance which has positive influence in the access to the bank loans for financing the SME-s investment. This means that the firms that posses business plan and use it for seeking bank loans necessary for financing investments, on average have higher growth of investments than the firms who do not have a business plan.

The variables trade and production are statistically significant, but they have negative influence in the growth of investments. This means that the firms that use bank loans for investment in the sector of trade and production, on average, have lower chance to grow, than firms in the service sector. This is an indicator that shows that the sector of services is more attractive in the aspect of investments of Kosovan firms, than other sectors of the economy, and this results from faster returns of investments and, consequently, faster settling up of the bank loans.

The next variable named as the number of owners also results positive and significant in the statistical aspect, which means that the larger the number of owners, the greater the investments. This is explained by the fact that in Kosovo firms have started to use other forms of organization that influence the growth of business and of firm, through larger number of owners who use investment as another opportunity for the growth and development of the firm.

The size of the firm expressed by the number of employees results with inverse influence in the growth of investments, and is statistically significant. The meaning of this is that smaller firms have bigger growth of investment on average than other firms. This result is in accordance with other studies that oppose the Gibrat's Law for the case of Kosovo (Krasniqi, 2010). Similar results are attained regarding the variable the age of the firm, which is statistically significant and has a negative sign, which means that the younger firms invest more on average than older firms.

Empirical evidence and findings in this work can be used as recommendations for a broad spectrum of users. The problems of asymmetric information between owners-managers and creditors (banks) are of particular importance. This represents a clear signal for policy makers to create conditions for favorable environment for stimulating the sources of external financing of SME-s in Kosovo, such as: the creation of the guarantee fund for SME-s, the increase of banking supply through licensing of new banks in the financial market, which will increase the competition between the existing banks, and which will, in turn, enable the improvement of the conditions of financing of SME-s, with the reduction of the interest, reduction of managerial costs, increase of the grace period, softening of the conditions for collateral, longer periods of use of financial means, particularly for SME-s that have longer investment plans. Also, in the institutional aspect, initiatives should be undertaken for the creation of conditions for development of entrepreneurial capabilities, and for other forms of cooperating networks of firms that will facilitate the growth of businesses in general, and investment growth in particular

\section{References}

Abor, J. (2008). Determinants of the capital structure of Ghanaian firms. Small Business Economics. Retrieved from http//www.aercafrica.org//documents/RP176.pdf

Acs, Z., \& Audretsch, D. (1990). Innovation and small firms. Cambridge: MIT Press. http://dx.doi.org/10.1007/978-94-015-7854-7

Ahn, S., Denis, D., \& Denis, D. (2006). Leverage and investment in diversified firms. Journal of Financial Economics, 79(1), 317-337. http://dx.doi.org/10.1016/jfineco.2005.03.002

Audretsch, D. B., \& Elston, J. (2006). Does firm size matter? Evidence on the impact of liquidity constraint on firm investment behavior in Germany. International Journal of Industrial Organization, 20(1), 1-17. http://dx.doi.org/10.1016/S0167-7187(00)00072-2

Audretsch, D. B., \& Klepper, S. (2000). Innovation, evolution of industry and economic growht: Elgar reference 
Collection. International Library of Critical Writings in Economics, Cheltenham, UK.

Barkham, R., Gudging, G., Hart, M., \& Hanvey, E. (1996). The determinants of small business growth: An interregional study in the UK 1986-90. London: Jessica Kingsley.

Baumol, W. (1967). Business behavior, value and growth. New York: MC Millan.

Beck, T. H. L., Demirguc-Kunt, A., \& Levine, R. (2007). Finance, inequality, and the poor. Journal of Economic Growth, 12, 27-49. http://dx.doi.org/10.1007/s10887-007-9010-6

Beck, T., Demirguc-Kunt, A., Laeven, L., \& Maksimovic, V. (2006). Financial and legal constraints to firm growth: Does firm size matter. Journal of Finance, 60, 137-177. http://dx.doi.org/10.1111/j.1540-6261.2005.00727.x

Brinckmann, J., Salomo, S., \& Gemuenden, H. G. (2011). Financial management competence of founding teams and growth of new technology-based firms. Entrepreneurship Theory and Practice, 35(2). http://dx.doi.org/10.1111/j.1540-6520.2009.00362.x

Caves, R. E. (1998). Industrial organization and new findings on the turnover and mobility of finance. Journal of Economic Literature, 36, 1947-1982.

Coleman, S. (2000). Access to capital and terms of credit: A comparison of men and women-owned small businesses. Journal of Small Business Management, 38(3), 37-52.

Curran, J. (1986). Bolton 15 years on: A review and analysis of small business research in Britain 1977-1986. Small Business Research Trust, London.

Deakins, D., North, D., Baldock, R., \& Whittam. (2008). SMEs access to finance: Is still finance gap? Institute for Small Business \& Entrepreneurship, 3, 11-19.

Donaldson, G. (1961). Corporate debt capacity: A study of corporate debt policy and the determination of corporate debt capacity. Harvard Graduate SBA, Boston, USA.

European Bank for Research and Development. (1999). Transition report: Ten years of transition. London, UK.

Fatoki, O., \& Asah, F. (2011). The impact of firms characteristics on access to debt finance by SMEs in King Williams' Town, South Africa. International Journal of Business and Management, 6(8). http://dx.doi.org/10.5539/ijbm.v6n8p170

Ganbold, B. (2008). Improving access to finance: International good experiences and lessons for Mongolia. Institute of Development Economics, Tokyo.

Gibrat, R. (1931). Les ine'galite's e'conomiques. Librairie du Recueil Sirey, Paris.

Guffey, M. E. (2008). Business communication: Process and product (6th ed.).

Harris, M., \& Raviv, A. (1991). The theory of capital structure. Journal of Finance, 46, 297-355. http://dx.doi.org/10.1111/j.1540-6261.1991.tb03753.x

Harris, R., \& Trainor, M. (2005). Capital subsidies and their impact on total factor productivity: Firm level evidence from Northern Island. Journal of Regional Science, 45(1), 49-74. http://doi:10.1111/j.0022-4146.2005.00364.x

Hartarska, V., \& Gonzales-Vega, C. (2006). What affects new established firms expansion: Evidence from small firms in Russia. Small Business Economics, 27, 195-206. http://dx.doi.org/10.1007/s11187-006-0012-0

Irwin, D., \& Scott, J. M. (2008). Barriers to raising bank finance faced by SMEs. Working paper no: MS_WPP_MAN_08_03.

Japelli, T., \& Pagano, M. (1994). Saving, growth and liquidity constraint. Quarterly Journal of Economics, 109, 83-109. http://dx.doi.org/10.2307/2118429

Jarvis, R., Kitching, J., Curran, J., \& Lighfoot, G. (2000). The use of quantitative and qualitative criteria in the measurement of performance in small firms. Journal of Small Business and Enterprize Development, 7(2), 123-134. http://dx.doi.org/10.1108/EUM0000000006834

Jensen, M., \& Meckling, W. (1976). Theory of the firm: Managerial behavior, agency cost and ownership structure. Journal of Financial Economics, 3, 305-360. http://dx.doi.org/10.1016/0304-405x/76/90026-x.

Johnson, S., \& Storey, D. (1993). Male and female entrepreneurs and their businesses: A comparative study. In S. Allen, \& C. Truman (Eds.), Women entrepreneurs. London: Routledge. 
Johnson, S., \& Loveman, G. (1995). Starting over in Eastern Europe. Entrepreneurship and Economics Review, 48(3), 261-297.

Jovanovic, B. (1982). Selection and the evolution of industry. Econometrica, 50, 649-670. http://dx.doi.org/10.2307/1912606

Kalleberg, A., \& Leicht, K. (1991). Gender and organizational performance: Determinants of small business survival and success. The Academy of Management Journal, 34(1), 136-161. http://dx.doi.org/10.2307/256305

Klapper, L., Sarria-Allende, V., \& Sulla, V. (2002). SME financing in Eastern Europe. Washington, DC: World Bank, Development Research Group. http://dx.doi.org/10.1596/1813-9450-2933

Kon, Y., \& Storey, D. J. (2003). A theory of discouraged borrowers. Small Business Economics, 21, 37-49. http://dx.doi.org/10.1023/A:1024447603600

Krasniqi, B. (2006). Size, age, and firm growth: Econometric evidence from SME sector in Kosova. International Journal of Management and Entrepreneurship, 2(1), 57-68.

Krasniqi, B. (2007). Barriers to entrepreneurship and SME growth in transition: The case of Kosova. Journal of Development Entrepreneurship, 12(1), 71-940. http://dx.doi.org/10.1142/S1084946707000563

Krasniqi, B. (2010). Are small firms really constrained? Empirical evidence from Kosova. International Entrepreneurship and Management Journal, 2(1), 57-68.

Lee, S., \& Ratti, R. (2008). Bank concentration and financial constraint on firm level in Europe. Department of Economics, University of Missuri, Columbia.

Madura, J. (2007). Introduction to Business (4th ed.). Thomson, USA: South Western.

Marris, R. (1963). A model of the "Managerial" enterprise. Quarterly Journal of economics, 72(2), 1-33.

Mayers, S. C., \& Majlyf, N. S. (1984). Corporate finance and investment decision: When firms have information that investors do not have. Journal of Financial Economics, 13(June), 187-222. http://dx.doi.org/10.1016/0304-405X(84)90023-0

Maziku, M. (2012). Credit rationing for small and medium scale enterprises in the commercial bank loan market. Tanzania: Dares Salaam.

Mazzani, M., \& Fatoki, O. (2012). Access to finance in SME sector: A south african perspective. Asian Journal of Business Management, 4(1), 58-67.

Mc Pearson, M. (1996). Growth of micro and small enterprise in Southern Africa. JDE, 48, 253-277. http://dx.doi.org/10.1016/0304-3878(95)00027-5

McMillan, J., \& Woodruff, C. (2002). The central role of entrepreneurs in transition economies. Journal of Economic Perspectives, 16(3), 153-170. http://dx.doi.org/10.1257/089533002760278767

Modigliani, F., \& Miller, M. (1958). The cost of capital, corporation finance and the theory of investment. American Economics Review, 48(3), 261-297.

Oliveira, B., \& Fortunato, A. (2006). Firms growth a liquidity constrains: A dynamic analysis. Small Business Economics, 27(1), 139-56. http://dx.doi.org/10.1007/s11187-006-0006-y

Ou, C., \& Haynes, G. W. (2006). Acquisition of additional equity capital by small firms-findings from the national survey of small firm finances. Small Business Economics, 27(2), 157-168. http://dx.doi.org//10.1007/s11187-006-0009-8

Pissardies, F., Singer, M., \& Svenjar, J. (2003). Objectives and constraint of entrepreneurs: Evidence from small and medium sized enterprises in Russia and Bulgaria. Journal of Comparative Economics, 31(3), 503-31. http://dx.doi.org/10.1016/S0147-5967(03)00054-4

Rand, J. (2007). Credit constraints and determinants of the cost of capital in vietnamese manufacturing. Small Business Economics, 2991, 1-13. http://dx.doi.org/10.1007/s 11187-005-1161-2

Scott, D. F. (1972). Evidence on the importance of financial structure. Journal of Finantial mangement, 1(3), 4560.

Stigitz, J. E., \& Weiss, A. (1981). Credit rationing in markets with imperfect information. American Economic Review, 71, 393-410.

Storey, D. (1994). The role of legal status in influencing bank financing and new firms growth. Applied 
Economics, 26, 129-136. http://dx.doi.org/10.1080/00036849400000068

Vos, E., Yeh, A., Carter, S., \& Tagg, S. (2007). The happy story of small business financing. Journal of Banking and Finance, 31, 2648-2672. http://dx.doi.org/10.1016/j.jbankfin.2006.09.011

Watson, J., Newby, R., \& Mahuka, A. (2009). Gender and SME finance gap. International Journal of Gender and Entrepreneurship, 1(1), 42-56. http://dx.doi.org/10.1108/17566260910942336

Woldie, A., Leighton, P., \& Adesua, A. (2008). Factors influencing Small and Medium Enterprises (SMEs). An explanatory study of owner-manager and firm characteristics. Bank and Bank Systems, 3(3).

World Bank. (2005). A better investment climate for everyone: World development report 2005. New York: The World Bank and Oxford University Press.

World Bank. (2010). Kosovo unlocking growth potential: Strategies, policies, actions.

Zhang, G. (2008). The choice of formal and informal finance: Evidence from Chengdu. Journal of China Economic Review, 19, 659-678. http://dx.doi.org/10.1016/j.chievo.2008.09.001

Zhao, H., Wu, W., \& Chen, X. (2006). What factors affects small and medium sized enterprise's ability to borrow from banks: Evidence from Chengdu City, Capital of South-Western China's Sichuan Province. Working paper no.23, Berlin School of Economics.

\section{Copyrights}

Copyright for this article is retained by the author(s), with first publication rights granted to the journal.

This is an open-access article distributed under the terms and conditions of the Creative Commons Attribution license (http://creativecommons.org/licenses/by/3.0/). 